\title{
Insulin Secretion by a Transplantable Rat Islet Cell Tumour
}

\author{
A. M. Sopwith ${ }^{1}$, J. C. Hutton ${ }^{1}$, S. P. Naber ${ }^{2}$, W. L. Chick ${ }^{2}$ and C. N. Hales ${ }^{1}$ \\ ${ }^{1}$ Department of Clinical Biochemistry, University of Cambridge, Addenbrooke's Hospital, Cambridge, UK and \\ ${ }^{2}$ Elliott P. Joslin Research Laboratory, Harvard Medical School and the Peter Bent Brigham Hospital, Boston, Massachusetts, USA
}

Summary. Investigation of the subcellular and molecular components of insulin secretion has been made difficult by the small quantities of material available. The recent development of a transplantable rat islet cell tumour of high insulin content and state of differentiation suggested a system more amenable to analysis. To validate the tumour as a model of secretion we have studied its release of insulin. In acute experiments in vitro immunoreactive insulin release was increased by leucine, glucagon, theophylline and dibutyryl cyclic AMP, though not by glucose. Leucine $(20 \mathrm{mmol} / \mathrm{l})$ plus theophylline $(5 \mathrm{mmol} / \mathrm{l})$ caused an abrupt, sustained and rapidly reversible stimulation of two- to fivefold. The response was inhibited by antagonists of cellular oxidative phosphorylation (cyanide, 2,4-dinitrophenol, antimycin A), calcium flux (EGTA, verapamil, $\mathrm{Mg}^{2+}$ ), calmodulin (trifluoperazine), microtubules (vinblastine, colchicine) and by adrenaline and somatostatin. These findings suggest that the tumour secretes insulin by an exocytotic mechanism similar to that of normal islet tissue.

Key words: Islet cell tumour, B cell, insulin secretion

The pancreatic B cell has proved difficult to investigate at the subcellular and molecular levels. The classical strategy of subcellular fractionation, purification and reassembly has been greatly hindered by the shortage of starting material $[3,4]$. In this context the description recently of a transplantable rat islet cell tumour is of considerable interest. The tumour contains large amounts of insulin and consists predominantly of well-granulated cells the morphology of which closely resembles that of rat $B$ cells $[1,2]$.

That this islet cell tumour might offer a largescale model of insulin secretion is an attractive possi- bility. Realisation of this potential, however, depends upon establishing that the tumour is indeed capable of the exocytosis of insulin. We here report a series of experiments in which the characteristics of insulin release by the tumour were defined. The effect of putative secretagogues, the dynamics of insulin release, and the influence of potentiators and inhibitors of secretion are described.

\section{Materials and Methods}

The islet cell tumour $[1,2]$ was maintained by serial subcutaneous transplantation within a colony of inbred albino NEDH strain rats $[2]$.

\section{Buffers}

Tissue was handled in a Krebs Ringer solution [5] containing $\mathrm{NaCl}$ $115 \mathrm{mmol} / \mathrm{l}, \quad \mathrm{KCl} \quad 5.0 \mathrm{mmol} / \mathrm{l}, \quad \mathrm{NaHCO}_{3} \quad 24 \mathrm{mmol} / 1, \quad \mathrm{MgCl}_{2}$ $1.0 \mathrm{mmol} / \mathrm{l}$ and $\mathrm{CaCl}_{2} 2.5 \mathrm{mmol} / \mathrm{l}$, freshly equilibrated with $5 \%$ $\mathrm{CO}_{2} 95 \% \mathrm{O}_{2}$. Except where specified glucose $2.8 \mathrm{mmol} / \mathrm{l}$, bovine plasma albumin (Armour Pharmaceuticals, Eastbourne, UK) $1.0 \mathrm{mg} / \mathrm{ml}$, and $5.0 \mathrm{mmol} / \mathrm{l}$ each of sodium pyruvate, monosodium glutamate and disodium fumarate were included (using $95 \mathrm{mmol} / 1$ $\mathrm{NaCl}$ to maintain the final sodium ion concentration at $139 \mathrm{mmol} /$ 1). When individual experiments required further additions the osmolality of control buffers was balanced using sucrose.

Chemicals were purchased from Fisons Scientific Apparatus, Loughborough, UK and British Drug House Chemicals, Poole, $\mathrm{UK}$, and were of the highest purity available.

\section{Incubations}

Tumours were speedily excised and placed in ice-cold buffer. For perifusion studies tumour was finely divided with scissors, washed once, and preincubated in a $37^{\circ} \mathrm{C}$ water bath for $45 \mathrm{~min}$. Fragments were transferred to a chamber containing a $25 \mathrm{~mm}$ diameter $5 \mu \mathrm{m}$ porosity polycarbonate filter (Nuclepore Corporation, Pleasanton, USA) and the chamber, inserted in line with a peristaltic pump delivering buffer at $2 \mathrm{ml} / \mathrm{min}$, replaced in the water bath. Due to high initial background release of insulin a stabilization period of $105 \mathrm{~min}$ preceded any experiment. 


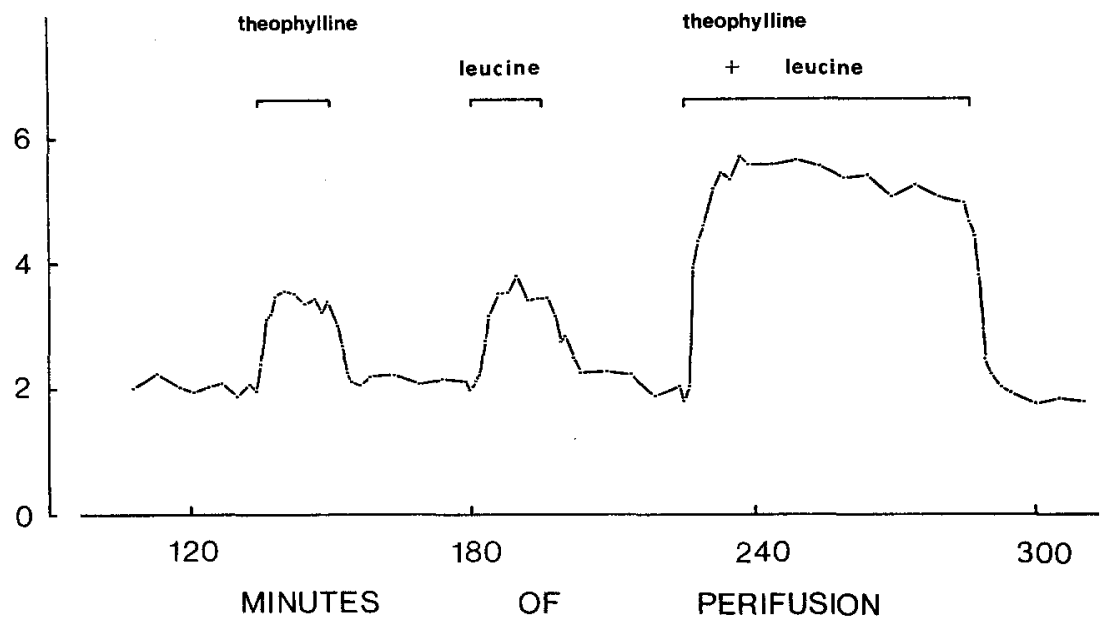

Fig. 1. Perifusion of the islet cell tumour: stimulation of insulin release by theophylline $(5 \mathrm{mmol} / \mathrm{l})$ and leucine $(20 \mathrm{mmol} / \mathrm{l})$ presented individually and in combination. Rate of insulin release was calculated as the percentage of tissue insulin content (i. e. $1570 \mathrm{mU}$ ) released per hour (see Materials and Methods). In four experiments the rate of basal insulin release was $10.1 \pm 1.92 \mathrm{mU} /$ $\mathrm{mg}$ tissue protein/h (mean $\pm \mathrm{SEM}$ ), increasing with theophylline to $16.6 \pm 2.67$, with leucine to $16.1 \pm 2.73$, and with theophylline plus leucine to $31.6 \pm 7.87 \mathrm{mU} / \mathrm{mg}$ tissue $\operatorname{protein} / \mathrm{h}$
For static incubation studies tumour cells were suspended by repeatedly expelling tumour fragments from a Pasteur pipette. Connective tissue was removed by filtering through nylon mesh. After washing four times (centrifuging at $600 \mathrm{~g}$ ) the cells were resuspended in a siliconised glass tube containing $20 \mathrm{ml}$ of buffer, and placed in a $37^{\circ} \mathrm{C}$ water bath. Four consecutive 60 min incubations followed, with hourly resuspension in fresh buffer, to allow background insulin release to stabilise. During the first hour $10 \%$ of tissue insulin was released into the supernatant, compared with $2-3 \%$ in the fourth. The cells were washed. Viewed by phase contrast microscopy the suspension contained tumour cells singly and in small clusters, accompanied by an occasional red blood cell. For counting, a sample of cells was disaggregated using $5 \mathrm{mmol} / \mathrm{l}$ EGTA: $60-80 \%$ of cells excluded trypan blue. The cells were aliquoted into capped plastic tubes (No. 72.690 from Walter Sarstedt (UK), Leicester, UK), washed, and resuspended each in $1.0 \mathrm{ml}$ of buffers containing the various test substances. The tubes were placed in glass vials which, after flushing with $5 \% \mathrm{CO}_{2} 95 \%$ $\mathrm{O}_{2}$ and capping, were returned to the $37^{\circ} \mathrm{C}$ water bath. On completing the final $60 \mathrm{~min}$ incubation the tubes were centrifuged $(4 \mathrm{~min}$ at $600 \mathrm{~g}, 1 \mathrm{~min}$ at $3000 \mathrm{~g}$ ) and the supernatants and pellets separated.

After each experiment residual tissue insulin was extracted overnight at $4{ }^{\circ} \mathrm{C}$ using a mixture $50: 16: 1$ by volume of absolute ethanol:water:1.18 sp. gr. $\mathrm{HCl}$. Immunoreactive insulin was determined [6] using guinea-pig antibovine insulin serum raised locally, and ${ }^{125}$ I-insulin from the Radiochemical Centre, Amersham, UK, or prepared from bovine insulin (Sigma, Poole, UK) by the iodogen method [7].

\section{Secretagogues and Inhibitors}

Antimycin A was purchased from Boehringer (London), Lewes, UK, verapamil was obtained as Cordilox from Abbot Laboratories Queenborough, UK, and trifluoperazine dihydrochloride was the gift of Smith Kline \& French Laboratories, Welwyn Garden City, UK. Other agents were purchased from British Drug House or Sigma. All were introduced in the final incubation buffer except verapamil, which was included in the preceding wash, and vinblastine and colchicine, each of which was also present during the final hour of preincubation.

\section{Data Presentation}

Between individual experiments there were variations both in basal release of insulin and in the additional release induced by secretagogues. To allow comparison and pooling of data from static experiments investigating different inhibitors, insulin release was expressed relative to the increment in insulin release induced in each experiment by the stimulus of leucine $(20 \mathrm{mmol} / \mathrm{l})$ plus theophylline $(5 \mathrm{mmol} / \mathrm{l})$; using the following ratio:

[(release in presence of inhibitor) - (basal release)]/

[(release in presence of stimulus alone) - (basal release)]

Basal insulin release was that release in the absence either of stimulus or inhibitor.

For similar reasons, and to aid comparison with the static incubation experiments, insulin released during each minute of perifusion was expressed as a rate:

(insulin in minute fraction/insulin content of tumour fragments) $\times 6,000=$ percentage tissue insulin content released per hour

Significance of differences was calculated using Student's $t$ test for unpaired data.

\section{Results}

\section{Secrètagogues}

In acute experiments no response by the islet cell tumour to glucose was detected. Stimulation was attempted using glucose concentrations of 8.4 to $48 \mathrm{mmol} / \mathrm{l}$, from a baseline of either zero or $2.8 \mathrm{mmol} / 1$ glucose, and in both the presence and absence of $5 \mathrm{mmol} / 1$ theophylline. Preincubation neither with $28 \mathrm{mmol} / 1$ glucose plus $20 \mathrm{mmol} / 1$ leucine for $60 \mathrm{~min}$, nor with $48 \mathrm{mmol} / 1$ glucose for 30 min conferred sensitivity to the subsequent presentation of glucose.

In contrast, increased release of insulin was provoked by leucine and by theophylline. Maximum response to leucine was obtained using $20 \mathrm{mmol} / 1$ and to theophylline using $5 \mathrm{mmol} / \mathrm{l}$. The typical effect of these concentrations in perifusion and static incubation experiments is illustrated in Figure 1 and 
Table 1. Static incubation of the islet cell tumour: stimulation of insulin release by theophylline and leucine, and by dibutyryl cyclic AMP. Insulin release during the hour of incubation is presented both as mean \pm SEM and as percentage tissue insulin content ( $46.5 \mathrm{mU} /$ individual incubation). The number of individual incubations in each group is shown in parentheses

\begin{tabular}{|c|c|c|}
\hline \multirow[b]{2}{*}{ Incubation condition } & \multicolumn{2}{|c|}{ Insulin released/h } \\
\hline & $\mathrm{mU}$ & $\begin{array}{l}\text { Proportion } \\
\text { of tissue } \\
\text { insulin } \\
(\%)\end{array}$ \\
\hline \multirow{4}{*}{$\begin{array}{l}\text { Basal } \\
\text { + theophylline }(5 \mathrm{mmol} / \mathrm{l}) \\
\text { + leucine }(20 \mathrm{mmol} / \mathrm{l}) \\
\text { + dibutyryl cyclic AMP } \\
\text { ( } 5 \mathrm{mmol} / \mathrm{l})\end{array}$} & $0.72 \pm 0.03$ & 1.6 \\
\hline & $1.31 \pm 0.07^{\mathrm{a}}$ & 2.8 \\
\hline & $1.13 \pm 0.04^{\mathrm{a}}(4)$ & 2.4 \\
\hline & $1.37 \pm 0.09^{\mathrm{a}}$ & 3.0 \\
\hline $\begin{array}{l}\text { theophylline }(5 \mathrm{mmol} / \mathrm{l}) \\
\text { leucine }(20 \mathrm{mmol} / \mathrm{l})\end{array}$ & $2.21 \pm 0.06^{\mathrm{a}}(6)$ & 4.8 \\
\hline
\end{tabular}

a Significant difference from basal release $(p<0.001)$

Table 2. Static incubation of the islet cell tumour: stimulation of insulin release by glucagon and by leucine plus theophylline in the same experiment. Tissue insulin content was $19.2 \mathrm{mU} /$ individual incubation. The number of individual incubations in each group was four

\begin{tabular}{lll}
\hline & \multicolumn{2}{l}{ Insulin released/h } \\
\cline { 2 - 3 } Incubation condition & $\begin{array}{l}\mathrm{mU} \\
(\mathrm{mean} \pm \mathrm{SEM})\end{array}$ & $\begin{array}{l}\text { Proportion } \\
\text { of tissue } \\
\text { insulin } \\
(\%)\end{array}$ \\
\hline Basal & & 1.6 \\
+ glucagon $(0.003 \mu \mathrm{mol} / \mathrm{l})$ & $0.32 \pm 0.01$ & 1.7 \\
+ glucagon $(0.03 \mu \mathrm{mol} / \mathrm{l})$ & $0.41 \pm 0.05$ & 2.1 \\
+ glucagon $(0.3 \mu \mathrm{mol} / \mathrm{l})$ & $0.61 \pm 0.07^{\mathrm{a}}$ & 3.2 \\
+ glucagon $(3.0 \mu \mu \mathrm{mol} / \mathrm{l})$ & $0.71 \pm 0.02^{\mathrm{b}}$ & 3.7 \\
theophylline $(5 \mathrm{mmol} / \mathrm{l})$ & $1.05 \pm 0.03^{\mathrm{b}}$ & $5.5 \%$ \\
\hline
\end{tabular}

a Significant difference from basal release $(p<0.01)$

b Significant difference from basal release $(p<0.001)$

Table 1. The tumour responded within $1 \mathrm{~min}$ of exposure to either compound. Combination of leucine with theophylline always caused an increase in insulin release greater than the sum of the responses to their individual challenge. In different experiments the response to the combined stimulus was an increase relative to basal insulin release of two- to fivefold, a rate equivalent to $3-5 \%$ of tissue insulin per hour. The immunoreactive insulin content of the tumour was $0.52 \pm 0.08$ units $/ \mathrm{mg}$ tissue protein (mean \pm standard error of 16 determinations).

Release of insulin from the tumour was also induced by dibutyryl cyclic AMP, the effect of
Table 3. Effect of sodium cyanide, 2,4-dinitrophenol and antimycin $\mathrm{A}$ on insulin release. Results are from four static incubation experiments, the number of individual observations in each group being shown in parentheses. The basal rate of insulin release was $19.2 \pm 1.2 \mathrm{mU} / \mathrm{mg}$ tissue protein $/ \mathrm{h}$ (mean $\pm \mathrm{SEM}$ ), rising on stimulation with leucine $(20 \mathrm{mmol} / \mathrm{l})$ plus theophylline $(5 \mathrm{mmol} / \mathrm{l})$ to $39.8 \pm 3.7 \mathrm{mU} / \mathrm{mg}$ tissue protein $/ \mathrm{h}$. Each result is expressed as the percentage of the increment observed upon stimulation

\begin{tabular}{|c|c|c|}
\hline \multirow{2}{*}{ Incubation condition } & \multicolumn{2}{|c|}{ Insulin released/h } \\
\hline & Basal & $\begin{array}{l}\text { Leucine/ } \\
\text { theophylline }\end{array}$ \\
\hline No addition & $0 \pm 2.2(21)$ & $100 \pm 4.9(10)$ \\
\hline $\begin{array}{l}+\mathrm{NaCN}(1.0 \mathrm{mmol} / \mathrm{l}) \\
+2,4 \text {-dinitrophenol }\end{array}$ & $4.4 \pm 4.8(10)$ & $15.1 \pm 5.9$ \\
\hline$(0.3 \mathrm{mmol} / 1)$ & $5.0 \pm 5.1$ & $-7.5 \pm 7.9$ \\
\hline+ Antimycin A $(5 \mu \mathrm{mol} / \mathrm{l}$ & $-3.9 \pm 4.3 \quad(9)$ & $-9.3 \pm 5.3$ \\
\hline
\end{tabular}

Table 4. Effect of low external calcium (EGTA), verapamil and magnesium chloride on insulin release. Results are from 10 experiments, the number of individual observations in each group being shown in parentheses. The basal rate of insulin release was $19.5 \pm$ $1.1 \mathrm{mU} / \mathrm{mg}$ tissue protein $/ \mathrm{h}$ (mean $\pm \mathrm{SEM}$ ), rising on stimulation with leucine $(20 \mathrm{mmol} / \mathrm{l})$ plus theophylline $(5 \mathrm{mmol} / \mathrm{l})$ to $38.9 \pm$ $2.7 \mathrm{mU} / \mathrm{mg}$ tissue protein/h. Each result is expressed as the percentage of the increment observed upon stimulation

\begin{tabular}{|c|c|c|}
\hline \multirow{2}{*}{ Incubation condition } & \multicolumn{2}{|l|}{ Insulin released $/ \mathrm{h}$} \\
\hline & Basal & $\begin{array}{l}\text { Leucine/ } \\
\text { theophylline }\end{array}$ \\
\hline No addition & $0 \pm 1.8(52)$ & $100 \pm 2.8(34)$ \\
\hline+ EGTA $(1 \mathrm{mmol} / \mathrm{l})$ & $14.9 \pm 5.5(11)$ & $34.6 \pm 7.7(11)$ \\
\hline + Verapamil $(10 \mu \mathrm{mol} / \mathrm{l})$ & $2.1 \pm 3.0(25)$ & $-4.2 \pm 10.5$ \\
\hline$+\mathrm{MgCl}_{2}(10 \mathrm{mmol} / \mathrm{l})$ & $-1.0 \pm 6.1$ & $28.2 \pm 3.4$ (9) \\
\hline
\end{tabular}

Table 5. Effect of trifluoperazine on insulin release. Results are from five static incubation experiments, the number of individual observations in each group being shown in parentheses. The basal rate of insulin release was $17.7 \pm 1.9 \mathrm{mU} / \mathrm{mg}$ tissue protein $/ \mathrm{h}$ (mean $\pm \mathrm{SEM}$ ), rising on stimulation with leucine $(20 \mathrm{mmol} / \mathrm{l})$ plus theophylline $(5 \mathrm{mmol} / \mathrm{l})$ to $36.2 \pm 2.7 \mathrm{mU} / \mathrm{mg}$ tissue protein/h. Each result is expressed as the percentage of the increment observed upon stimulation

\begin{tabular}{lcl}
\hline Incubation condition & \multicolumn{2}{l}{ Insulin released/h } \\
\cline { 2 - 3 } & Basal & $\begin{array}{l}\text { Leucine/ } \\
\text { theophylline }\end{array}$ \\
\hline $\begin{array}{l}\text { No addition } \\
+ \text { Trifluoperazine }\end{array}$ & $0 \pm 2.2(28)$ & $100 \pm 5.3(17)$ \\
$\begin{array}{l}(3.5 \mu \mathrm{mol} / \mathrm{l}) \\
+\begin{array}{l}\text { Trifluoperazine } \\
(10 \mu \mathrm{mol} / \mathrm{l})\end{array}\end{array}$ & $5.3 \pm 2.4 \quad(5)$ & $29.1 \pm 4.7 \quad(5)$ \\
\hline
\end{tabular}


Table 6. Effect of vinblastine and colchicine on insulin release. Results are from three static incubation experiments, the number of individual observations in each group being shown in parentheses. The basal rate of insulin release was $17.6 \pm 2.9 \mathrm{mU} / \mathrm{mg}$ tissue protein/h (mean $\pm \mathrm{SEM}$ ), rising on stimulation with leucine $(20 \mathrm{mmol} / \mathrm{l})$ plus theophylline $(5 \mathrm{mmol} / \mathrm{l})$ to $34.3 \pm 2.9 \mathrm{mU} / \mathrm{mg}$ tissue protein $/ \mathrm{h}$. Each result is expressed as the percentage of the increment observed upon stimulation

\begin{tabular}{lcll}
\hline & \multicolumn{3}{l}{ Insulin released/h } \\
\cline { 2 - 4 } Incubation condition & Basal & $\begin{array}{l}\text { Leucine/ } \\
\text { theophylline }\end{array}$ \\
\hline $\begin{array}{l}\text { No addition } \\
+ \text { Vinblastine } \\
(0.01 \mathrm{mmol} / \mathrm{l})\end{array}$ & $0 \pm 3.0(15)$ & $100 \pm 4.2 \quad(17)$ \\
$+\begin{array}{c}\text { Vinblastine } \\
0.1 \mathrm{mmol} / \mathrm{l})\end{array}$ & $21.8 \pm 5.1 \quad(4)$ & $30.1 \pm 6.5^{\mathrm{a}} \quad(10)$ \\
$+\begin{array}{c}\text { Colchicine } \\
(0.1 \mathrm{mmol} / \mathrm{l})\end{array}$ & $6.8 \pm 4.8 \quad(5)$ & $98.5 \pm 5.0 \quad(5)$ \\
$+\begin{array}{c}\text { Colchicine } \\
(1.0 \mathrm{mmol} / \mathrm{l})\end{array}$ & $14.6 \pm 5.3 \quad(4)$ & $46.2 \pm 5.2^{\mathrm{b}} \quad(12)$
\end{tabular}

a Significant difference from release induced by leucine/theophylline in the same experiment $(p<0.01)$

b Significant difference from release induced by leucine/theophylline in the same experiment $(p<0.001)$

Table 7. Effect of adrenaline and somatostatin on insulin release. Results are from six experiments, the number of individual observations in each group being shown in parentheses. The basal rate of insulin release was $15.9 \pm 1.7 \mathrm{mU} / \mathrm{mg}$ tissue protein $/ \mathrm{h}$ (mean \pm SEM), rising on stimulation with leucine $(20 \mathrm{mmol} / \mathrm{l})$ plus theophylline $(5 \mathrm{mmol} / \mathrm{l})$ to $36.1 \pm 4.7 \mathrm{mU} / \mathrm{mg}$ tissue insulin $/ \mathrm{h}$. Each result is expressed as the percentage of the increment observed upon stimulation

\begin{tabular}{|c|c|c|}
\hline \multirow{2}{*}{ Incubation condition } & \multicolumn{2}{|l|}{ Insulin released $/ \mathrm{h}$} \\
\hline & Basal & $\begin{array}{l}\text { Leucine/ } \\
\text { theophylline }\end{array}$ \\
\hline No addition & $0 \pm 2.2(27)$ & $100 \pm 3.1$ \\
\hline+ Adrenaline $(5 \mu \mathrm{mol} / \mathrm{l})$ & $1.3 \pm 5.7$ & $30.2 \pm 2.0$ \\
\hline+ Adrenaline $(10 \mu \mathrm{mol} / \mathrm{l})$ & $-3.0 \pm 1.6$ & $-4.8 \pm 3.9$ \\
\hline+ Somatostatin $(1 \mu \mathrm{mol} / \mathrm{l})$ & $7.2 \pm 5.1$ & $67.9 \pm 5.4^{\mathrm{a}}(12)$ \\
\hline + Somatostatin $(5 \mu \mathrm{mol} / \mathrm{l})$ & $10.1 \pm 6.0$ & $71.1 \pm 2.4^{\mathrm{b}}$ \\
\hline
\end{tabular}

a Significant difference from release induced by leucine/theophylline in the same experiment $(p<0.01)$

b Significant difference from release induced by leucine/theophylline in the same experiment $(p<0.001)$

$5 \mathrm{mmol} / \mathrm{l}$ being shown in Table 1 . The dose-dependent stimulation by glucagon of insulin release is shown in Table 2.

In the above experiments buffers were supplemented with $2.8 \mathrm{mmol} / \mathrm{l}$ glucose and $5.0 \mathrm{mmol} / 1$ each of pyruvate, glutamate and fumarate. The dependence on this supplementation of the responses to leucine and theophylline was examined. Following the usual preincubation and perifusion run-in using supplemented buffer, a buffer lacking these additions was substituted. After exposure to this unsupplemented buffer for either 15 or 60 min theophylline and leucine were individually introduced. Each caused brisk increases in insulin release comparable to those previously obtained; baseline change was seen neither on substitution with simple buffer nor on reversion to the supplemented buffer.

\section{Inhibitors}

A selection of potential inhibitors was tested against the combined stimulation of leucine $(20 \mathrm{mmol} / \mathrm{l})$ plus theophylline $(5 \mathrm{mmol} / 1)$. Reduction of stimulated insulin release by the respiratory inhibitors sodium cyanide $(1.0 \mathrm{mmol} / \mathrm{l})$ and antimycin A $(5.0 \mu \mathrm{mol} / \mathrm{l})$, and by the uncoupler of oxidative phosphorylation 2,4-DNP $(0.3 \mathrm{mmol} / \mathrm{l})$ is shown in Table 3 . To allow comparison of data from different experiments results are expressed relative to the increase in insulin release induced by leucine plus theophylline in each experiment (as described under Methods).

The calcium dependency of stimulated insulin release was explored by omitting calcium chloride from the buffer, sodium EGTA $(1.0 \mathrm{mmol} / \mathrm{l})$ being added to chelate residual calcium ions. Alternatively, the addition to calcium-containing buffer of either verapamil $(10 \mu \mathrm{mol} / \mathrm{l})$ or magnesium chloride $(10 \mathrm{mmol} / \mathrm{l})$ was tested. In all instances a reduction in insulin release was obtained (Table 4). In data not shown, the presence of lanthanum chloride ( $3 \mathrm{mmol} / \mathrm{l})$ or cobaltous chloride $(10 \mathrm{mmol} / \mathrm{l})$ also markedly inhibited induced insulin release.

Inhibition of stimulated insulin release by trifluoperazine $(3.5$ and $10 \mu \mathrm{mol} / \mathrm{l})$ is illustrated in Table 5. With higher concentrations of this agent basal insulin release was increased: the presence of $30 \mu \mathrm{mol} / 1$ caused the baseline to double. From Table 6 can be seen the effects of vinblastine $(0.01$ and $0.1 \mathrm{mmol} / \mathrm{l})$ and colchicine $(0.1$ and $1.0 \mathrm{mmol} / \mathrm{l})$. Both substances reduced stimulated insulin release. Their tendency to increase basal insulin release became significant $(p<0.05)$ in the presence of $0.1 \mathrm{mmol} / 1$ vinblastine.

The powerful inhibitory action of adrenaline (5.0 and $10 \mu \mathrm{mol} / \mathrm{l})$ on the responsiveness of the tumour is shown in Table 7 . Inhibition by somatostatin (1.0 and $5.0 \mu \mathrm{mol} / \mathrm{l}$ ) is also shown.

\section{Discussion}

The tumour, if shown capable of the exocytosis of insulin, would provide secretory material in greater quantity than is obtainable by isolating islets; and of 
far higher insulin content and degree of differentiation than that from previously studied islet cell tumours $[2,9,10]$. The characteristics of insulin secretion by pancreatic $\mathrm{B}$ cells have been described in detail [for reviews see 3,8 ]. To this extent criteria of normal insulin secretion exist that may be applied to a proposed model.

Both leucine and theophylline stimulated insulin release by the tumour. The release closely tracked square-wave pulses of either compound, and exhibited potentiation if the compounds were presented simultaneously. Stimulation by dibutyryl cyclic AMP and by glucagon, and inhibition by adrenaline, further implied adenosine $3^{\prime}: 5^{\prime}$ cyclic monophosphate modulation of insulin release by the islet cell tumour [11]. Insensitivity to glucose in acute experiments may be an intrinsic characteristic of the tumour, or may reflect the study of tissue from a hypoglycaemic environment analogous to gross starvation $[12,13]$. It is of interest that in some cases cells cultured for $24-48 \mathrm{~h}$ in medium containing $16.5 \mathrm{mmol} / \mathrm{l}$ glucose released significantly more insulin than cells cultured in $5.5 \mathrm{mmol} / 1$ glucose (Naber and Chick, unpublished observations).

This pattern of acute stimulation by leucine, glucagon and theophylline, but not by glucose, is found in fetal islet tissue [14-17]. Sensitivity to glucagon, theophylline and dibutyryl cyclic AMP, but not to glucose has been reported of a hamster insulinoma $[9,10]$.

The responsiveness of the tumour was further investigated using inhibitors. Insulin release in response to leucine plus theophylline was eliminated by interference with cellular oxidative phosphorylation, as is insulin secretion by islet tissue $[18,19]$.

Calcium dependence was indicated by the reduced responsiveness of the tumour on lowering the external concentration of calcium ions [20]. The involvement of calcium in induced insulin release was confirmed by the inhibitory action of verapamil, whose blockade of transmembrane calcium ion movements $[21,22]$ and inhibition of islet insulin secretion [23] are well documented. Finally, the response of the tumour was inhibited by elevating the external concentration of $\mathrm{Mg}^{2+}$ or by adding $\mathrm{Co}^{2+}$ or $\mathrm{La}^{3+}$ ions. The same manipulations of islet tissue have been shown to perturb membrane electrical activity and $\mathrm{Ca}^{2+}$ handling, and to inhibit insulin secretion [20, 24-27].

Calmodulin is a widely distributed calcium binding protein that may mediate the effect of changes in intracellular calcium ion concentration $[28,29]$. This protein has recently been identified in rat islets [ 30 , 31], and the calmodulin inhibitor trifluoperazine [32] found to inhibit insulin secretion [30]. A similar action of trifluoperazine on insulin release induced from the tumour was demonstrated.

Induced insulin release was also inhibited by vinblastine and colchicine. While additional actions have been proposed, the disruption by these compounds of microtubules is well recognised, as is their inhibition of pancreatic islet secretion [33-35]. Their slight stimulation of basal insulin release from the tumour is unexplained, although apparently paradoxical effects of vincristine and colchicine have been described in islets $[34,35]$. Finally, reduction of insulin release by the tumour in response to leucine plus theophylline was achieved using either adrenaline or somatostatin. Both agents inhibit insulin secretion by islet tissue [36-39].

In conclusion, the findings show that the islet cell tumour releases insulin in response to specific stimuli. The data further suggest that this release of insulin occurs by an exocytotic process which requires cellular energy, movement of calcium ions and the integrity of the microtubular system, and in which calmodulin and cyclic nucleotides participate. The tumour may thus possess a stimulus-secretion coupling mechanism very similar to that of pancreatic islet tissue, and therefore may be used as a largescale model of the insulin secretory process.

Acknowledgements. AMS was supported by Novo Laboratories, UK, JCH is a C. J. Martin Fellow of the National Health and Medical Research Council of Australia, and WLC is an Established Investigator of the American Diabetes Association. We are grateful to Mrs. Lee Creswell for secretarial assistance. The work was supported in part by the British Diabetic Association and by NIH grant AM-15398.

\section{References}

1. Chick WL, Warren S, Chute RN, Lauris V (1976) A transplantable rat insulinoma. Diabetes 25: 344

2. Chick WL, Warren S, Chute RN, Like AA, Lauris V, Kitchen KC (1977) A transplantable insulinoma in the rat. Proc Natl Acad Sci USA 74: 628-632

3. Hedeskov CJ (1980) Mechanism of glucose-induced insulin secretion. Physiol Rev 60: 442-509

4. Evans WH (1978) Preparation and characterisation of mammalian plasma membranes. North-Holland Publishing Co, Amsterdam New York Oxford, pp 213-215

5. Dawson RMC (1968) Physiological media. In: Dawson RMC, Elliott DC, Elliott WH, Jones KM (eds) Data for biochemical research. Oxford University Press, p 507

6. Wright PH, Makulu DR, Malaisse WJ, Roberts NM, Yu P-L (1968) A method for the immunoassay of insulin. Diabetes 17: $537-546$

7. Fraker PJ, Speck JC Jr (1978) Protein and cell membrane iodinations with a sparingly soluble chloroamide 1,3,4,6-tetrachloro-3a,6a-diphenylglycouril. Biochem Biophys Res Commun 80: 849-857

8. Lambert AE (1976) The regulation of insulin secretion. Rev Physiol Biochem Pharmacol 75: 97-159 
9. Shapiro S, Eto S, Fleischer N, Baum SG (1975) Regulation of in vitro insulin release from a transplantable Syrian hamster insulinoma. Endocrinology 97: 442-447

10. Shapiro S, Kaneko Y, Baum SG, Fleischer N (1977) The role of calcium in insulin release from hamster insulinoma cells. Endocrinology 101: 485-493

11. Sutherland EW, Øye I, Butcher RW (1965). The action of epinephrine and the role of the adenyl cyclase system in hormone actions. In: Pincus $G$ (ed) Recent progress in hormone research XXI. Academic Press, New York, pp 623-646

12. Malaisse WJ, Malaisse-Lagae F, Wright PH (1967) Effect of fasting upon insulin secretion in the rat. Am J Physiol 213: 843-848

13. Buchanan KD, Vance JE, Williams RH (1969). Effect of starvation on insulin and glucagon release from isolated islets of Langerhans of the rat. Metab Clin Exp 18: 155-162

14. Lambert AE, Junod A, Stauffacher W, Jeanrenaud B, Renold AE (Steinbrinck R) (1969) Organ culture of fetal rat pancreas I. Insulin release induced by caffeine and by sugars and some derivatives. Biochim Biophys Acta 184: 529-539

15. Lambert AE, Jeanrenaud B, Junod A, Renold AE, Steinbrinck R (1969) Organ culture of fetal rat pancreas II. Insulin release induced by amino and organic acids, by hormonal peptides, by cationic alterations of the medium and by other agents. Biochim Biophys Acta 184: 540-553

16. Grodsky GM (1970). Insulin and the pancreas. Vitam Horm 28: 37-101

17. Lernmark A, Wenngren BI (1972) Insulin and glucagon release from the isolated pancreas of foetal and newborn mice. J Embryol Exp Morphol 28: 607-614

18. Coore HG, Randle PJ (1964) Regulation of insulin secretion studied with pieces of rabbit pancreas incubated in vitro. Biochem J 93: 66-78

19. Milner RDG, Hales CN (1969) The interaction of various inhibitors and stimuli of insulin release studied with rabbit pancreas in vitro, Biochem J 113: 473-479

20. Hellman B, Anderson T, Berggren P-O, Flatt P, Gylfe E, Kohnert K-D (1979) The role of calcium in insulin secretion. In: Dumont J, Nunez J (eds) Hormones and cell regulation, Vol 3. Elsevier/North-Holland Biomedical Press, Amsterdam, pp 69-96

21. Naylor WG, Szeto J (1972) Effect of verapamil on contractility, oxygen utilisation, and calcium exchangeability in mammalian heart muscle. Cardiovasc Res 6: 120-128

22. Malaisse WJ, Herchuelz A, Levy J, Sener A (1977) Calcium antagonists and islet function III. The possible site of action of verapamil. Biochem Pharmacol 26: 735-740

23. Devis G, Somers G, van Obberghen E, Malaisse WJ (1975) Calcium antagonists and islet function I. Inhibition of insulin release by verapamil. Diabetes $24: 547-551$

24. Hales CN, Milner RDG (1968) Cations and the secretion of insulin from rabbit pancreas in vitro. J Physiol (Lond) 199: 177-187

25. Malaisse WJ, Devis G, Herchuelz A, Sener A, Somers G (1976) Calcium antagonists and islet function VIII. The effect of magnesium. Diabete Metab 2: 1-4
26. Henquin J-C, Lambert AE (1975) Cobalt inhibition of insulin secretion and calcium uptake by isolated rat islets. Am J Physiol 228: 1669-1677

27. Preissler M, Meissner HP (1978) Effects of calcium on the electrical activity of single pancreatic B-cells. Diabetologia 15 : 262

28. Cheung WY (1980) Calmodulin plays a pivotal role in cellular regulation. Science 207: 19-27

29. Means AR, Dedman JR (1980) Calmodulin - an intracellular calcium receptor. Nature 285: 73-77

30. Sugden MC, Christie MR, Ashcroft SJH (1979) Presence and possible role of calcium dependent regulator (calmodulin) in rat islets of Langerhans. FEBS Lett 105: 95-100

31. Valverde I, Vandermeers A, Anjaneyulu R, Malaisse WJ (1979) Calmodulin activation of adenylate cyclase in pancreatic islets. Science 206: 225-227

32. Levin RM, Weiss B (1977) Binding of trifluoperazine to the calcium-dependent activator of cyclic nucleotide phosphodiesterase. Mol Pharmacol 13: 690-697

33. Malaisse WJ, Malisse-Lagae F, Walker MO, Lacy PE (1971) The stimulus-secretion coupling of glucose-induced insulin release $\mathrm{V}$. The participation of a microtubular-microfilamentous system. Diabetes 20: 257-265

34. Devis G, van Obberghen E, Somers G, Malaisse-Lagae F, Orc L, Malaisse WJ (1974) Dynamics of insulin release and microtubular-microfilamentous system II. Effect of vincristine. Diabetologia 10: 53-59

35. Somers G, van Obberghen E, Devis G, Ravazzola M, Malaisse-Lagae F, Malaisse WJ (1974) Dynamics of insulin release and microtubular-microfilamentous system III. Effect of colchicine upon glucose-induced insulin secretion. Eur $\mathbf{J}$ Clin Invest 4: 299-305

36. Porte D Jr (1967) A receptor mechanism for the inhibition of insulin release by epinephrine in man. J Clin Invest 46: 86-94

37. Malaisse W, Malaisse-Lagae F, Wright PH, Ashmore J (1969) Effects of adrenergic and cholinergic agents upon insulin secretion in vitro. Endocrinology 80: 975-97.8

38. Alberti KGMM, Christensen NJ, Christensen SE, Hansen AP, Inversen J, Lundbaek K, Seyer-Hansen K, Ørskov H (1973) Inhibition of insulin secretion by somatostatin. Lancet 2 : 1299-1301

39. Koerker DJ, Ruch W, Chideckel E, Palmer J, Goodner CJ, Ensinck J, Gale CC (1974) Somatostatin: hypothalamic inhibitor of endocrine pancreas. Science 184: 482-484

Received: 24 November 1980

and in revised form: 25 February 1981

Dr. A. M. Sopwith

Department of Clinical Biochemistry

University of Cambridge

Addenbrooke's Hospital

Hills Road

Cambridge CB2 2QR, UK 